[Article]

\title{
漆酶催化邻苯二酚开环的自由基反应机制
}

\author{
陈 明 ${ }^{1}$ 王 林 $^{2}$ 谭 天 $^{1}$ 罗学才 ${ }^{2}$ 郑 在 $^{2}$ \\ 尹若春 $^{2} \quad$ 苏吉虎 $^{1, *} \quad$ 杜江峰 $^{1}$ \\ ( ${ }^{1}$ 中国科学技术大学近代物理系, 中国科学院微观磁共振重点实验室, 合肥 230026; \\ 2 安徽大学生命科学学院生物制造创意中心, 合肥 230601)
}

\begin{abstract}
摘要: 酶催化反应是绿色化学领域中的研究热点之一。在常用的酶中, 漆酶是一种多铜氧化酶。在此, 漆酶 被用来研究邻苯二酚的氧化和芳香环开环的自由基过程。实验表明, 邻苯二酚的初始氧化产物是一个半醌自 由基, 再发生分子间加成反应而生成二聚体和三聚体(通过质谱鉴定), 和分子内加成而生成可被 5,5-二甲基1-氧化吡咯啉(DMPO)所捕获的含有支链烷基自由基的呋喃衍生物。后者经核磁共振氢谱('H-NMR)加以分 析。同时, 通过 ${ }^{17} \mathrm{O}$ 同位素标记追踪方法, 我们发现水直接参与该分子内加成反应, 并释放出 ${ }^{17} \mathrm{O}$ 标记的羟基 自由基 $\left(\cdot{ }^{17} \mathrm{OH}\right)$ 。此外，除了 3-甲基邻苯二酚和 4-甲基邻苯二酚两种类似物，此自由基过程在间苯二酚、对苯 二酚、菜二酚、3-硝基邻苯二酚和 4-硝基邻苯二酚等底物中均未发生。据此, 我们对 $\mathrm{C}_{4}-\mathrm{C}_{5}$ 位点的选择性活 化与开环的机理展开分析和讨论, 并将该机理与邻苯二酚双加氧酶导致的邻苯二酚双氧中间位置和相邻位置 的开环过程相比较。这些结果将有益于湮酶的改造和仿生。
\end{abstract}

关键词: 漆酶; 自由基氧化; 芳香环开环; 电子顺磁共振波谱; 自旋捕获技术 中图分类号 : 0643

\section{Radical Mechanism of Laccase-Catalyzed Catechol Ring-Opening}

\author{
CHEN Ming ${ }^{1} \quad$ WANG Lin $^{2}$ \\ TAN Tian ${ }^{1}$ \\ LUO Xue-Cai \\ ZHENG Zai ${ }^{2}$ \\ YIN Ruo-Chun ${ }^{2}$ \\ $\mathrm{SU} \mathrm{Ji}-\mathrm{Hu}^{1, *}$ \\ DU Jiang-Feng ${ }^{1}$ \\ ('CAS Key Laboratory of Microscale Magnetic Resonance, Department of Modern Physics, \\ University of Science and Technology of China, Hefei 230026, P. R. China; \\ ${ }_{2}^{2}$ Inspiration Center for Bio-manufacture, School of Life Sciences, Anhui University, Hefei 230601, P. R. China)
}

\begin{abstract}
Enzyme-catalyzed reactions are a prominent field of research in green chemistry. Laccase is a multicopper oxidase, which we used to study the oxidation of catechol. A mechanism for this ring-opening reaction is also proposed. A o-benzosemiquinone radical was the initial nascent product of catechol oxidation during the catalytic reaction. This radical underwent two reaction pathways: (1) formation of an intramolecular adduct, which gave a carbon-centered furan-derived radical trapped by 5,5-dimethyl-1-pyrroline- $\mathrm{N}$-oxide (DMPO); (2) formation of an intermolecular adduct producing dimeric and trimeric oligomers, as resolved by mass spectrometry. Products of the furan-like intermediate were also characterized by ${ }^{1} \mathrm{H}-\mathrm{NMR}$. Simultaneously, a hydroxyl radical $(\cdot \mathrm{OH})$ originating from the water solvent was identified by ${ }^{17} \mathrm{O}$-isotope tracing. The kinetics of this radical were also evident with substrates including 3-and 4-methyl catechol, but not with resorcinol and hydroquinone isomers, 3- and 4-nitro catechol, and 2,3-dihydroxynaphthalene. The mechanism of selective
\end{abstract}

Received: September 29, 2016; Revised: December 1, 2016; Published online: December 1, 2016.

"Corresponding author. Email: sujihu@ustc.edu.cn; Tel: +86-551-63607672.

The project was supported by the National Key Basic Research Program of China (973) (2013CB921802), and Fundamental Research Funds for the Central Universities, China, State Key Laboratory for Conservation and Utilization of Subtropical Agro-bioresources, China (KSL-CUSAb-2012-03). 国家重点基础研究发展规划项目(973) (2013CB921802)和亚热带农业生物资源保护与利用国家重点实验室开放课题基金(KSL-CUSAb-201203)资助 
activation and ring-opening at the $\mathrm{C}_{4}-\mathrm{C}_{5}$ site is discussed. This reaction is distinct from intra- and extra-diol ringcleavages catalyzed by catechol dioxygenase. These results are meaningful for mimicking laccase catalysis to further protein design.

Key Words: Laccase; Radical oxidation; Aromatic ring cleavage; Electron paramagnetic resonance spectroscopy; Spin trapping

\section{Introduction}

Laccase (benzenediol: oxygen oxidoreductase, EC1.10.3.2), belongs to a family of multicopper oxidases found in bacteria, fungi, green plants, and insects ${ }^{1-4}$. The active center of laccase is composed of four inorganic copper ions that are assigned respectively to $T_{1}$ and $T_{2} / T_{3}$ sites (Fig.1). The $T_{1}$ site consists of one redox-active $\mathrm{Cu}^{2+}$ ion which is reduced to $\mathrm{Cu}^{1+}$ after accepting an electron from the substrate donor, and then is turned back to thermal-stable $\mathrm{Cu}^{2+}$ after delivering the electron to downstream acceptor; The $\mathrm{T}_{2} / \mathrm{T}_{3}$ sites contain $3 \mathrm{Cu}$ clusters that reduce $\mathrm{O}_{2}$ to water after accepting four electrons from $T_{1}$ in steps ${ }^{1-3,5}$. The redox changes of $T_{1}$ and $T_{2} / T_{3} \mathrm{Cu}$ ions coupled with electron transfer within laccase has been elucidated ${ }^{1-3,5,6}$.

Because of the high redox potential, laccase-catalyzed transformations have recently become an active research field in chemistry $^{7-10}$ and biology ${ }^{11-14}$. For example, an ever-increasing focus on laccase mediated reaction has been shown in oxidation, polymerization and adduction reactions ${ }^{1,2,15-17}$. These processes are always involved with the cleavage and formation of chemical bonds and the electron transfer. Unfortunately, the substrate-dependent mechanism of substrate transformation in $T_{1}$ site is seldom studied. This is thus unclear when compared to the well-established electron transfer pathway from $\mathrm{T}_{1}$ to $\mathrm{O}_{2}$ via $\mathrm{T}_{2} / \mathrm{T}_{3}$ sites ${ }^{1-3,5}$. As for the potential application and protein designment, the mechanism must be elucidated experimentally. Moreover, the product/intermediates released from $\mathrm{Cu}-\mathrm{T}_{1}$ are more important than the $\mathrm{O}_{2}$-to-water transformation at $\mathrm{T}_{2} / \mathrm{T}_{3}$ sites. This question was addressed herein with catechol and analogs as laccase substrate.

Among laccase's substrates, phenols are of importance because of their uses as the building blocks in industry, agriculture, medicine, synthesis and polymer chemistry ${ }^{18}$. Catechol (o-dihydroxybenzene), a typical derivative of phenol, plays a key role in physiological activities ${ }^{18-21}$. A number of substrate analogs, $m$ - and p-dihydroxybenzene (resorcinoland hydroquinone), 3- or 4-methyl catechol, 3- or 4-nitroso catechol, and 2,3-dihydroxynaphthalene, were also used to study the mechanism clearly.

\section{Materials and methods}

Laccase $\left(\mathrm{EC} 1.10 .3 .2,>10 \mathrm{U} \cdot \mathrm{mg}^{-1}\right)$ is purchased from SigmaAldrich. Catechol (99\%) and analogs in Scheme 1 are purchased from J\&K Scientific. Trapping reactant, 5,5-dimethyl-1-pyrroline$N$-oxide (DMPO) (>99.0\%), is from Dojindo International. The reaction solution with double stilled water contains laccase and catechol or its analogues with the final $\mathrm{pH}$ 6.3. After 5- or 15-min reaction, $200 \mu \mathrm{L}$ of mixture was sampled for the following experiments. Analogs (Scheme 1), as well as $m$ - and $p$-dihydroxybenzene (resorcinoland hydroquinone), 3- or 4-methyl catechol (98\%), 3- or 4-nitroso catechol (98\%), and 2,3-dihydroxynaphthalene $(98 \%)$, were used as controls. Ethyl acetate was high performance liquid chromatography (HPLC) grade and purchased from Tianjin Guangfu fine chemical research institute.

After 5- or 15-min procedure reactions at room temperature, $200 \mu \mathrm{L}$ of solution contains laccase $\left(0.5 \mathrm{mg} \cdot \mathrm{mL}^{-1}\right)$ and catechol or its analogues $\left(0.5 \mathrm{mg} \cdot \mathrm{mL}^{-1}\right)$ was sampled, and then stored quickly in liquid nitrogen until electron paramagnetic resonance (EPR) measurement. The freeze-trapping EPR spectra were recorded with a Bruker X-band EMX EPR spectrometer at $20 \mathrm{~K}$.

For spin-trapping, $200 \mu \mathrm{L}$ of reaction mixture has laccase $(0.25$ $\left.\mathrm{mg} \cdot \mathrm{mL}^{-1}\right)$, catechol or phenol derivative $\left(0.25 \mathrm{mg} \cdot \mathrm{mL}^{-1}\right)$, DMPO

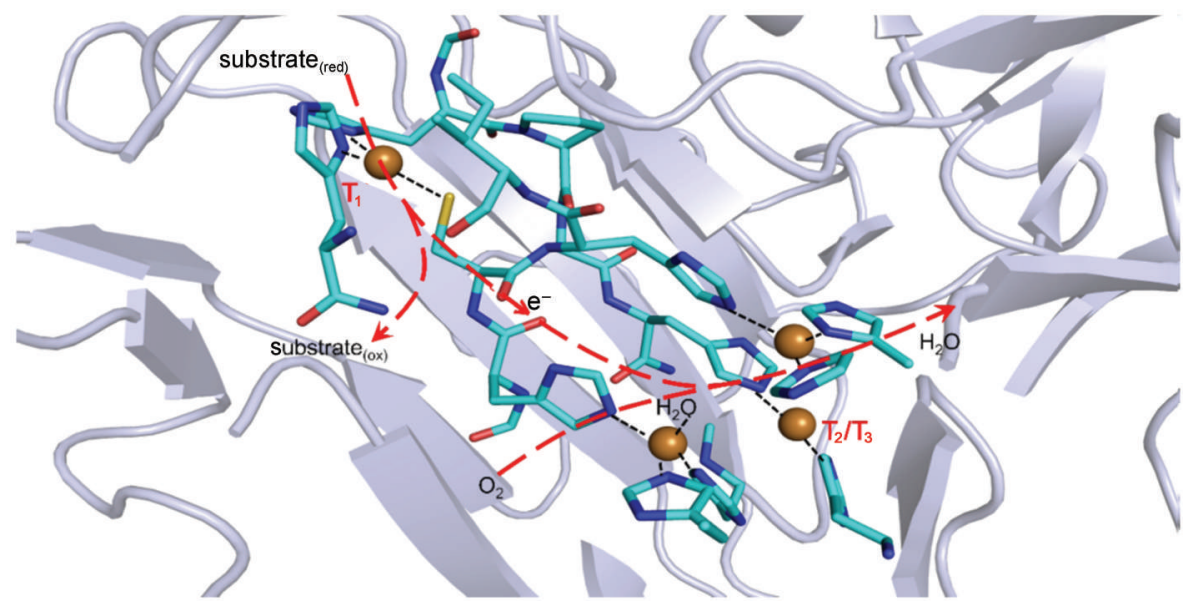

Fig.1 Core structure and electron transfer in blue laccase from Lentinus tigrinus (PDB code 2QT6) 


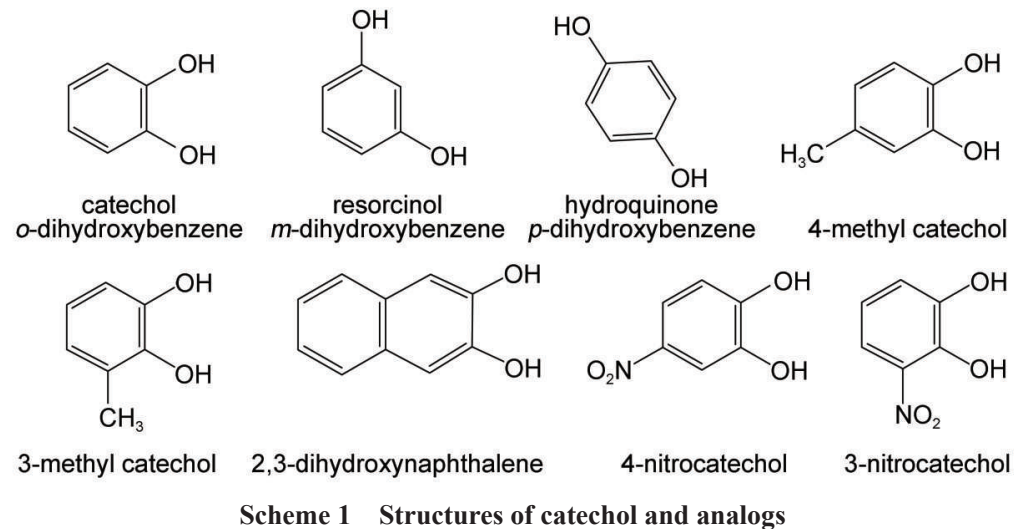

$\left(100 \mathrm{mmol} \cdot \mathrm{L}^{-1}\right)$. The reaction was preceded at room temperature about 3-4 min, then trapping reagent DMPO was added swiftly to trap the radicals for EPR measurements (Scheme 2) at room temperature.

HPLC-MS (mass spectrometry) was performed with the Waters Xevo G2 QTof. The catalytic reaction containing $1 \mathrm{mg} \cdot \mathrm{mL}^{-1}$ laccase and the corresponding substrates were preceded about 5 min at room temperature. The sampled mixture was filtered first through a $0.45-\mu \mathrm{m}$ filter membrane before injection. The HPLCMS settings were: mobile phase, acetonitrile/water (20\%/80\%); flow velocity, $0.3 \mathrm{~mL} \cdot \mathrm{min}^{-1}$; inject volume, $2 \mu \mathrm{L}$. The other settings are: scanning mode, anion mode; ion source, electrospray ionization (ESI). The actual mass is to be added by one proton unit (1.0078).

The ${ }^{1} \mathrm{H}$ NMR experiments were performed with the (400-MHz) Bruker AVANCE III 400 NMR spectrometer. The samples were prepared as follows. Aliquots of catalysis $(100 \mathrm{~mL}$ in $500-\mathrm{mL}$ Erlenmeyer flasks) were prepared using $50 \mu \mathrm{g} \cdot \mathrm{mL}^{-1}$ catechol and $0.2 \mathrm{mg} \cdot \mathrm{mL}^{-1}$ laccase. After $30 \mathrm{~min}$ procedure reactions in an orbital shaker maintained at $200 \mathrm{r} \cdot \mathrm{min}^{-1}$ and $30^{\circ} \mathrm{C}$, products were extracted 3 times with the same volume of precooled ethyl acetate $\left(4{ }^{\circ} \mathrm{C}\right)$. Then the products were purified by silica gel column chromatography and C-18 reversed-phase chromatography. Extracts were evaporated to dryness using an Eppendorf Vacufuge (Eppendorf Scientific, Westbury, NY) at $30^{\circ} \mathrm{C}$. The sample was then subjected to ${ }^{1} \mathrm{H}$ NMR analysis.

\section{Results and discussion}

Generally, the oxidase-catalyzed reactions are always involved with the short-lived free radicals during the cleavage and re-arrangement of the activated bonds ${ }^{22-24}$. To trap these transient radical species, the reactions are stopped either by the in situ swiftly freezing in cryogenic liquid nitrogen $(77 \mathrm{~K})$, or by room-

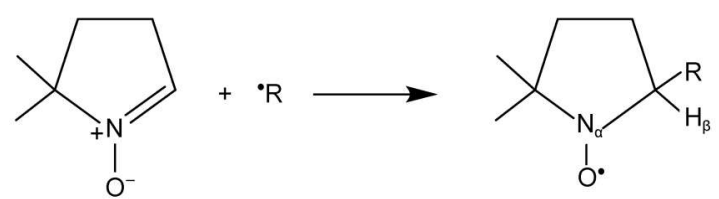

Scheme 2 DMPO trapping reaction temperature spin trapping using DMPO. The latter allows structurally configuration of the radical species through the isotropic hyperfine constants ( $h f c s$, indicated by $a$ ) of $\alpha$-nitrogen and $\beta$ hydrogen (i.e., $a_{\mathrm{N}}$ and $\left.a_{\mathrm{H} \beta}\right)^{25,26}$.

Fig.2a displays the time-course change of EPR signal stabilized by freeze trapping. A broadened and strong signal was observed after $5 \mathrm{~min}$ of reaction, and the signal decreased dramatically when the reaction was elongated to $15 \mathrm{~min}$. This EPR signal has a symmetrical feature at $g \sim 2.004$ showing a 7 -G peak-to-trough width. It is assigned to the $o$-benzosemiquinone radical, the direct product of catechol oxidation. The continuous decreasing in EPR signal indicates that the $o$-benzosemiquinone radical was depleted in the sequential reaction. In the meantime, Q-Tof mass spectrometry (i.e., HPLC-MS) was performed to detect the products. Fig.2(b, c) shows that substrate catechol $\left(\mathrm{C}_{6} \mathrm{H}_{6} \mathrm{O}_{2}\right)$ was converted dominantly to the dimer $\left(\mathrm{C}_{12} \mathrm{H}_{8} \mathrm{O}_{4}\right.$ and $\left.\mathrm{C}_{12} \mathrm{H}_{10} \mathrm{O}_{4}\right)$ and partly to the trimer $\left(\mathrm{C}_{18} \mathrm{H}_{12} \mathrm{O}_{6}\right)$ (see mechanism in Scheme 3 below). Evidently, this oligomerization removes the $o$-benzosemiquinone radical, thereby abolishing the corresponding EPR signal (Fig.2a). Fig.2e shows a new absorption (marked by an arrow) observed at $\sim 5.8$ min with identical molecule weight to substrate catechol (at $\sim 2.2$ $\mathrm{min})$. The lag effect is ascribed to its weak polarity compared with that of catechol. Under the identical condition, oligomers and the lagging signal were not observed in the parallel experiments with two isomers ( $m$ - and $p$-dihydroxybenzene), as well as in the parent controls with the absence of either catechol or laccase (Fig.2b). Therefore this lagging signal indicates isomerization of the $o$ benzosemiquinone radical, i.e., it suggests that the formed isomer is also a radical species.

With room-temperature spin trapping protocol, two radical species were trapped in situ by DMPO (Fig.3a). i) For DMPO- • OH adduct radical, the isotropic hyperfine coupling constants $(h f c s)$ of $\alpha$-nitrogen and $\beta$-proton characterized by $a_{\mathrm{N}}=a_{\mathrm{H} \beta}=14.8 \mathrm{G}$ lead to the four-line (1:2:2:1) spectrum; ii) For carbon-centered DMPO adduct radical, $a_{\mathrm{N}}=15.6 \mathrm{G}$ and $a_{\mathrm{H} \beta}=22.8 \mathrm{G}$ were obtained from the six-line hyperfine pattern. In the parallel experiments, these two transient radicals were not observed by replacement of catechol with $m$ - or $p$-dihydroxybenzene isomers (Fig.4). In order to clarify the origin of $\cdot \mathrm{OH}$ radical, the ${ }^{17} \mathrm{O}$ isotope-labeling solvent water $\left(\mathrm{H}_{2}{ }^{17} \mathrm{O}, \sim 80 \%\right.$ (atomic fraction) ${ }^{17} \mathrm{O}$ ) was used. 

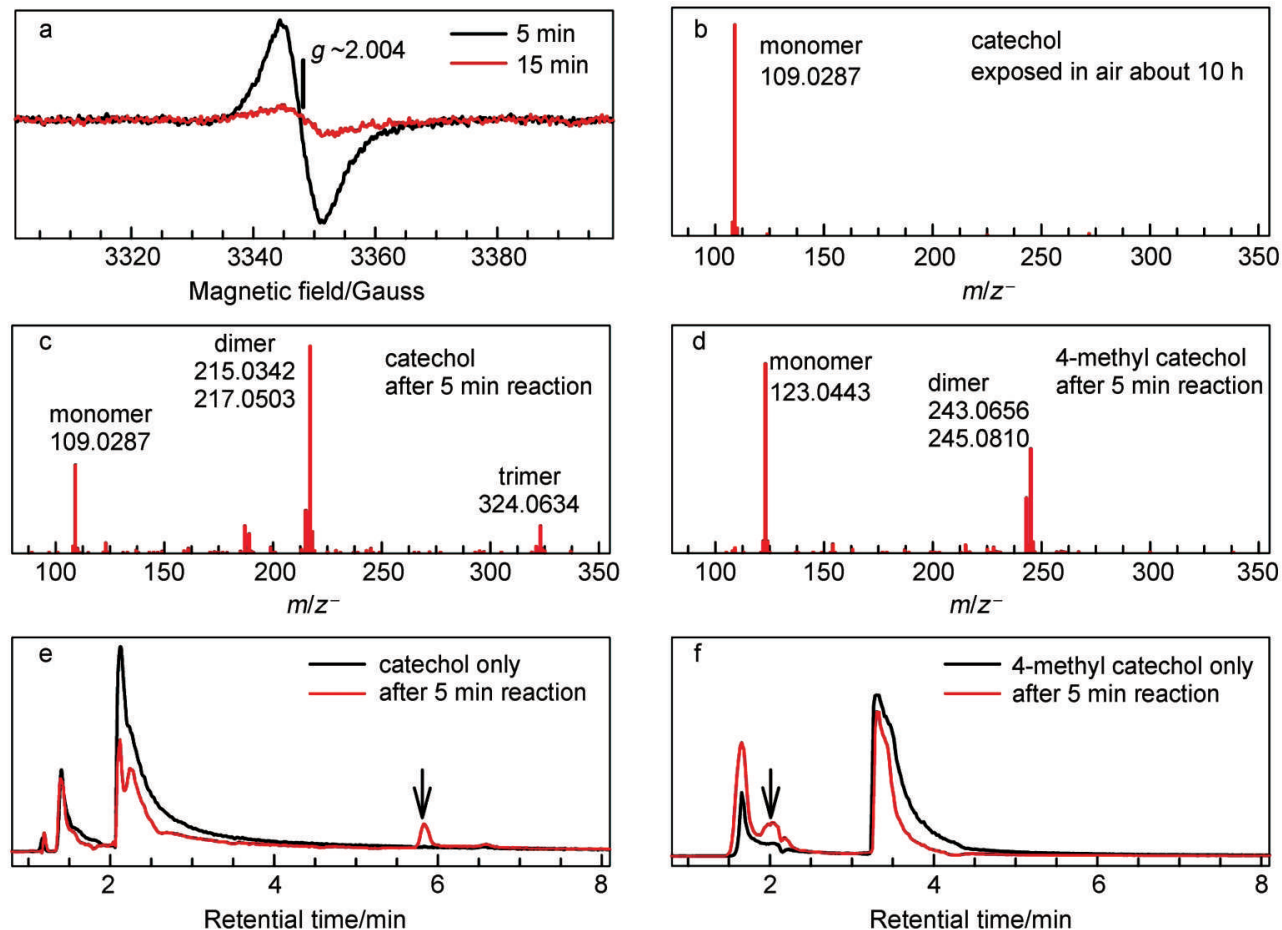

Fig.2 (a) X-band (9.39 GHz) EPR spectra recorded to monitor the metastable radicals upon the laccase-catalyzed oxidation of catechol trapped by freezing trapping; (b-d) anion-mode HPLC-MS from control substrate self-oxidized at ambient condition;

(e,f) corresponding HPLC-MS spectra from catechol/4-methyl catechol and after 5 min of reaction with laccase

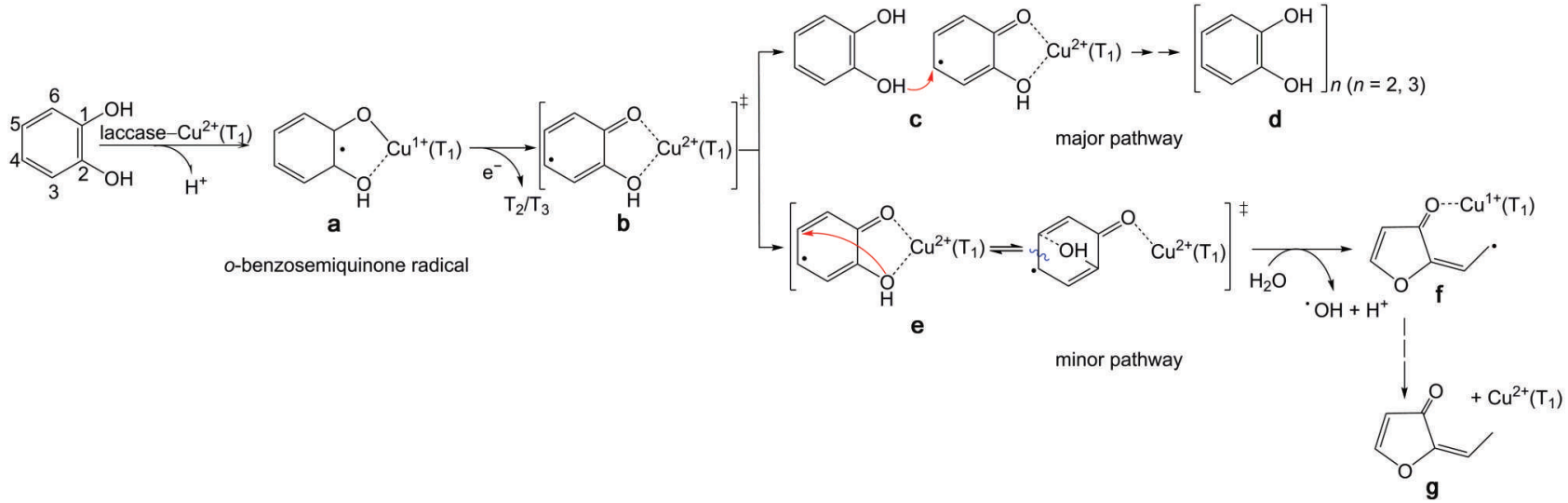

Scheme 3 Proposed mechanism of the laccase-catalyzed extra- and intra-molecular adducts of catechol

Experimentally, the four-line EPR signal of the DMPO- $\cdot{ }^{16} \mathrm{OH}$ radical $\left({ }^{16} \mathrm{O}, 99.757 \%\right.$ nature abundance $)$ was replaced by a weaker signal, due to the further hyperfine splitting of ${ }^{17} \mathrm{O}(I=5 / 2)$ of DMPO- ${ }^{17} \mathrm{OH}$ radical $\left(a_{\mathrm{N}}=a_{\mathrm{H} \beta}=14.8 \mathrm{G}\right.$, and $\left.a_{170}=4.6 \mathrm{G}\right)$. Moreover, removal of the DMPO- $\cdot{ }^{16} \mathrm{OH}$ radical signal by ${ }^{17} \mathrm{O}$ isotope unambiguously demonstrated that the other oxygencentered radicals (e.g., peroxide, acyl, aroyl or alkoxyl radicals) were not formed. Notably, the $o$-benzosemiquinone radical could not be trapped by DMPO. Obviously, solvent water was a substrate upon the oxidative reaction, which has not been reported so far. Simultaneously, the six- line carbon-centered signal was prominently protruded because of the elimination of the DMPO- ${ }^{16} \mathrm{OH}$ radical after adding ${ }^{17} \mathrm{O}$-labeled water. The remaining question lies with whether the carbon-centered radical is aromatic or non-aromatic species originating from catechol oxidation? We rule out the former which gives $a_{\mathrm{N}}$ and $a_{\mathrm{H} \beta}$ values larger than those of the latter ${ }^{25,26}$. Since the other oxygen-centered radicals were not observed experimentally, these two radicals were probably not released from the intra- (at $\mathrm{C}_{1}-\mathrm{C}_{2}$ site) or extra-diol (at $\mathrm{C}_{1}-\mathrm{C}_{6}$ site) cleavages which was similar to those in catalysis by catechol dioxygenase or in chemical oxidation ${ }^{20,21,27-32}$. Therefore, the trapped non-aromatic carbon-centered radical was assigned to the isomer of the $o$-benzosemiquinone radical, which was also detected in HPLC-MS (Fig.2e). To collect the intermediates, the catalyzed reaction was stopped after 30 min by adding ethyl acetate for extraction. The crude extraction by chromatography was subjected to ${ }^{1} \mathrm{H}-\mathrm{NMR}$ measurement in $\mathrm{d}_{6}$-DMSO. Fig.3b shows that a new group of ${ }^{1} \mathrm{H}$ signal in the extraction was appeared at $\delta \sim$ 

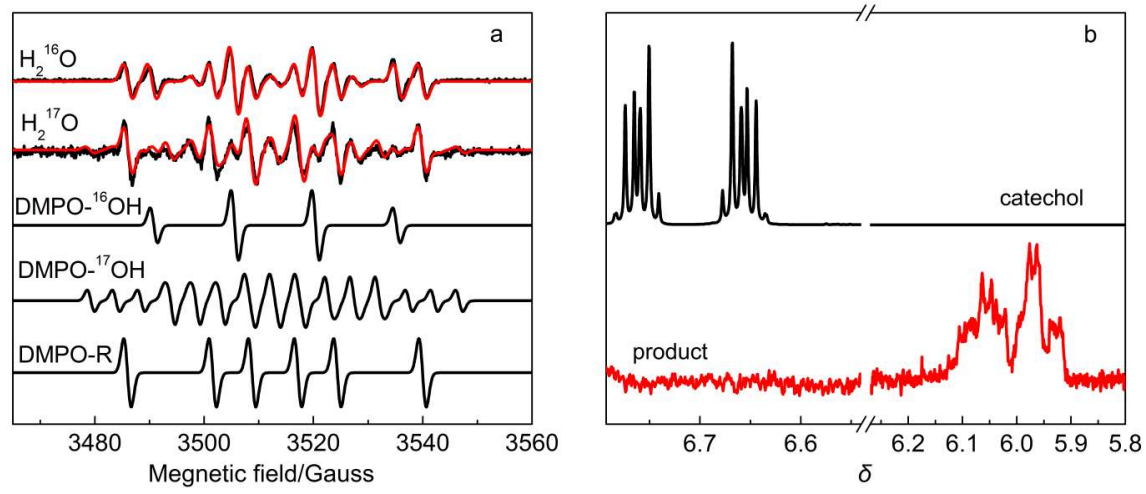

Fig.3 (a) Room temperature X-band $(9.86 \mathrm{GHz})$ EPR spectra and simulation of DMPO adduct radicals after 5 min of laccase-catalyzed oxidation in the normal $\left(\mathrm{H}_{2}{ }^{16} \mathrm{O}\right)$ or ${ }^{17} \mathrm{O}$-labeled $\left(\mathrm{H}_{2}{ }^{17} \mathrm{O}, \sim 80 \%\right.$ (atomic fraction) $\left.{ }^{17} \mathrm{O}\right)$ aqueous solution; (b) compared ${ }^{1} \mathrm{H}-\mathrm{NMR}$ spectra of substrate catechol (black) and product (red)

6.0 at the expensed of those $(\delta \sim 6.7)$ of substrate catechol, and this novel ${ }^{1} \mathrm{H}$ signal was assigned to the oxole derivant (i.e., the furan derivative $)^{33-36}$.

For the uncoupled $o$-benzosemiquinone radical, the isotropic $h f c s$ of $a_{\mathrm{H} 4,5}=3.56 \mathrm{G}$ and $a_{\mathrm{H} 3,6}=0.9 \mathrm{G}$ are known for two sets of two equivalent protons ${ }^{18,24}$. The larger $h f c$ of $a_{\mathrm{H} 4,5}$ indicates that a large positive spin density is localized at $\mathrm{C}_{4,5}$ and it is negative at $\mathrm{H}_{4,5}{ }^{18,24}$. Under the self-oxidized conditions, the oligomeric or adductive products were not detected. Obviously, the formed $o$ benzosemiquinone radical alone does not yield any adduct product. When adding laccase, a chelate complex was formed between the $o$-benzosemiquinone radical and the counterion $\mathrm{Cu}^{1+}$ / $\mathrm{Cu}^{2+}\left(\mathrm{T}_{1}\right)^{19-21,27-32}$. The inductive effect caused by $\mathrm{Cu}$ ion activates the cation radical tendency at the $\mathrm{C}_{4}-\mathrm{C}_{5}$ site. This is proved by the dimer and trimmer formed efficiently from the inter-molecular adduct on the $\mathrm{C}_{4}-\mathrm{C}_{5}$ site $^{37,38}$. In particular, the trapped non-aromatic carbon-centered radical is probably an isomer derived from the intramolecular adduct of the $o$-benzosemiquinone radical. To test the hypothesis, analogues of catechol were surveyed comparatively. In Fig.4, when isomers ( $m$ - and $p$-dihydroxybenzene) were oxidized by laccase, neither the radicals trapped by DMPO nor the oligomers were observed, as well as 3- or 4-nitroso catechol, and 2,3-dihydroxynaphthalene. However, formations of DMPOtrapped radicals and dimerization were not affected in the presence of 3- or 4-methyl catechol (Fig.1(d, f) and Fig.4). Again, none of the other oxygen-centered radicals was observed in the parallel experiments.

To describe the laccase-catalyzed inter- and intra-molecular adducts of catechol, a mechanism is proposed in Scheme 3, with comparison to the well-established mechanism of catechol dioxygenase ${ }^{20,21,27-30}$. Upon catalysis, $\mathrm{Cu}^{2+}\left(\mathrm{T}_{1}\right)$ is reduced firstly to the metastable $\mathrm{Cu}^{1+}\left(\mathrm{T}_{1}\right)$ and catechol is oxidized to the o-benzosemiquinone radical. Chemical turnover from $\mathrm{Cu}^{1+}\left(\mathrm{T}_{1}\right)$ to $\mathrm{Cu}^{2+}\left(\mathrm{T}_{1}\right)$ is accomplished after delivering an electron to the downstream. At $\mathrm{T}_{2} / \mathrm{T}_{3}$ sites, $\mathrm{O}_{2}$ is reduced to $\mathrm{H}_{2} \mathrm{O}$ after accepting four electrons from $\mathrm{T}_{1}$ (Fig.1). Interaction between the incipient $o$-benzosemiquinone radical and the counterion $\mathrm{Cu}^{2+}\left(\mathrm{T}_{1}\right)$ yields a chelate intermediate as $\mathbf{b}$ in Scheme 3. $\mathrm{Cu}^{2+}$ in the chelate induces further spin density transfer such that the nascent cation radical character at the $\mathrm{C}_{4}-\mathrm{C}_{5}$ site is fulfilled actively. The intermolecular addition reaction from $\mathbf{c}$ to $\mathbf{d}$ is the major pathway which can be regarded as the mimic bio-synthesis of biological macromolecules, e.g., lignin. Inevitably, the $\mathrm{C}_{4}-\mathrm{C}_{5}$ bond is also attacked by the intramolecular hydroxyl group during the transition from $\mathbf{e}$ to $\mathbf{g}$ via $\mathbf{f}$ (depicted as the minor pathway in Scheme 3). The intermediates f and $\mathbf{g}$ were characterized by EPR and ${ }^{1} \mathrm{H}-\mathrm{NMR}$ respectively (Fig.3). The intramolecular adduct gives to the sidechain carboncentered furan-derivative radical when the cleavage of $\mathrm{C}_{4}-\mathrm{C}_{5}$ bond occurs. This ring-opening is accomplished with synergy of substrate water that is ascertained when the origin of hydroxyl radical is identified by ${ }^{17} \mathrm{O}$-labeling water $\left(\mathrm{H}_{2}{ }^{17} \mathrm{O}\right)$. Simultaneously, $\mathrm{Cu}^{2+}\left(\mathrm{T}_{1}\right)$ is reduced to $\mathrm{Cu}^{1+}\left(\mathrm{T}_{1}\right)$ once again. To further determine the inductive effect of spin density transfer, some derivatives of catechol are applied as substrates. Formations of the DMPOtrapped radicals and dimer are not affected in the presence of 3or 4-methyl catechol substrates (methyl group causing the electron-

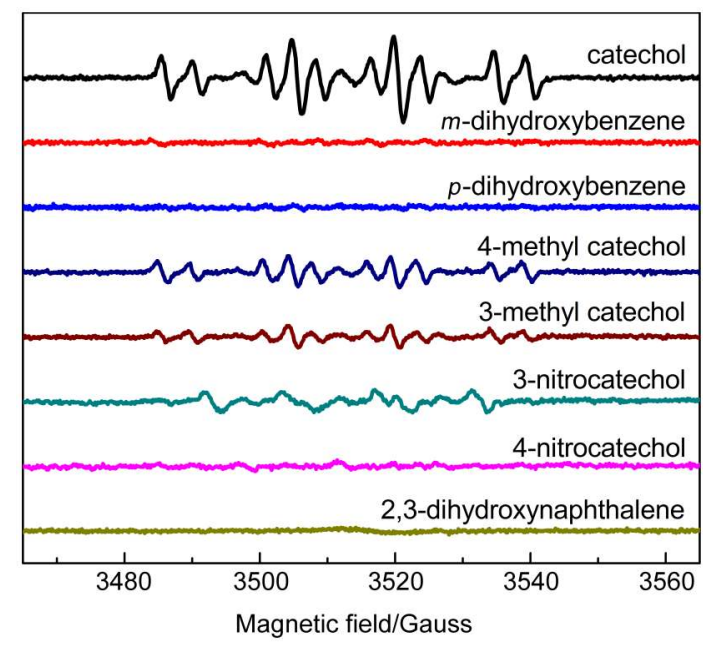

Fig.4 Room temperature EPR spectra of DMPO spin trapping in the presence of a variety of substrate catechol analogs: $\boldsymbol{m}$ - and p-dihydroxybenzene, 3- or 4-methyl catechol substrate, 3- or 4-nitroso catechol, and 2,3-dihydroxynaphthalene 
donating inductive effects). Contrarily, these reactions are prohibited in the presence of 3- or 4-nitro catechol $\left(-\mathrm{NO}_{2}\right.$ group causing the electron-withdrawing inductive effects), as well as in the presence of 2,3-dihydroxynaphthalene. When formation of the chelate complex is prevented in the presence of $m$ - and $p$-dihydroxybenzene, all these results are not observed any more.

This mechanism reminds us of another oxidation mechanism of catechol catalyzed by dioxygenase. Although the protein ligation to $\mathrm{Cu}^{2+}\left(\mathrm{T}_{1}\right)$ is more or less similar to that around $\mathrm{Fe}^{2+}$ in catechol dioxygenase ${ }^{19-21}$, the inductive effects of spin density transfer on the substrate oxidation are distinguished from each other. For dioxygenase, catechol and $\mathrm{O}_{2}$ substrates binding and ring-opening are carried out simultaneously in adjacent position ${ }^{19-21}$. The distinct catalytic mechanisms of catechol dioxygenase and laccase provide the first-hand evidence for further understanding and utilization of $\mathrm{Fe} / \mathrm{Cu}$ co-catalysis and synergy ${ }^{39}$. These comparative results show that the radical transformation can be mimicked if the electronic structure between substrate intermediate(s) and catalytic ion center can be adjusted biologically or chemically. In addition to the aromatic building block for oligomerization, the transient furan-derivative radical might have potential application in flavor chemistry, or phenols' antioxidation and interaction of multicopper oxidase in vivo with degenerative diseases such as cancer, heart disease, inflammation and even ageing ${ }^{18}$. This also sheds light on the further comprehension of laccase-catalyzed transformation in PAHs biodegradation, green chemistry, and flavor industry.

\section{Conclusions}

Phenol oxidation and transformation catalyzed by laccase was studied mechanistically with mass spectrometry and EPR. The data shows that the chelate interacting between $\mathrm{Cu}^{2+}\left(\mathrm{T}_{1}\right)$ ion and $o$-benzosemiquinone radical plays a pivotal role to direct the subsequent inter- or intra-molecular adducts, i.e., oligomerization or isomerization correspondingly, when the electronic structure of the chelate was altered purposely by the different modified catechol analogs. The proposed mechanism is helpful to understand the distinct catalysis of $\mathrm{Cu}$ and $\mathrm{Fe}$ that induce different electron spin transfer in the short-lived intermediates. This also shows that the radical transformation can be mimicked if the electronic structure between substrate intermediate(s) and catalytic ion center can be adjusted biologically or chemically to further exploit the utilization of laccase.

\section{References}

(1) Solomon, E. I.; Sundaram, U. M.; Machonkin, T. E. Chem. Rev. 1996, 96, 2563. doi: 10.1021/cr950046o

(2) Solomon, E. I.; Heppner, D. E.; Johnston, E. M.; Ginsbach, J. W.; Cirera, J.; Qayyum, M.; Kieber-Emmons, M. T.; Kjaergaard, C. H.; Hadt, R. G.; Tian, L. Chem. Rev. 2014, 114, 3659. doi: $10.1021 / \mathrm{cr} 400327 \mathrm{t}$

(3) ten Have, R.; Teunissen, P. J. M. Chem. Rev. 2001, 101, 3397. doi: $10.1021 / \mathrm{cr} 0001151$

(4) Jiang, B.; Xu, X. Y.; Li, Z. Y. Chin. J. Org. Chem. 2008, 28,
1715. [姜 标, 徐向亚, 李祖义. 有机化学, 2008, 28, 1715.]

(5) Lee, S. K.; George, S. D.; Antholine, W. E.; Hedman, B.; Hodgson, K. O.; Solomon, E. I. J. Am. Chem. Soc. 2002, 124, 6180. doi: 10.1021/Ja0114052.

(6) Hua, J. L.; Song, C. S.; Wang, G. H.; Cai, M. Z. Acta Phys. -Chim. Sin. 1999, 15, 173. [花建丽, 宋才生, 王光辉, 蔡明中. 物理化学学报, 1999, 15, 173.] doi: 10.3866/PKU WHXB19990215

(7) Ma, G. X.; Zhong, Q. D.; Lu, T. H. Sci. China Chem. 2010, 53, 1332. doi: 10.1007/s11426-010-3186-x

(8) Zeng, H.; Liao, L. W.; Li, M. F.; Tao, Q.; Kang, J.; Chen, Y. X. Acta Phys. -Chim. Sin. 2010, 26, 3217. [曾 涵, 廖铃文, 李明芳, 陶 骞, 康 婧, 陈艳霞. 物理化学学报, 2010, 26, 3217.] doi: 10.3866/Pku.Whxb20101208

(9) Zhang, Q.; Zhang, Y. Q.; Liu, X. Z.; Liang, Y. X.; Zhang, R. F.; Long, N. B. Chin. J. Inorg. Chem. 2013, 29, 2065. [张 群, 张育淇, 刘晓贞, 梁云霄, 张瑞丰, 龙能兵. 无机化学学报, 2013, 29, 2065.] doi: 10.3969/j.issn.1001-4861.2013.00.324

(10) Li, Y.; Jiang, G. X.; Niu, J. F.; Wang, Y.; Hu, L. J. Prog. Chem. 2009, 21, 2028. [李阳, 蒋国翔, 牛军峰, 王颖, 呼丽娟. 化学进展, 2009, 21, 2028.]

(11) Gupta, A.; Aartsma, T. J.; Canters, G. W. J. Am. Chem. Soc. 2014, 136, 2707. doi: 10.1021/ja411078b

(12) Drauz, K.; Gröger, H.; May, O. Enzyme Catalysis in Organic Synthesis, 3rd ed.; Drauz, K., Gröger, H., May, O. Eds.; WileyVCH: Weinheim, 2012.

(13) Polaina, J.; MacCabe, A. P. Industrial Enzymes : Structure, Function, and Applications; Springer: Dordrecht, 2007.

(14) Xu, F.; Damhus, T.; Danielsen, S.; Østergaard, L. H. Catalytic Applications of Laccase. In Modern Biooxidation, Wiley-VCH Verlag GmbH \& Co. KGaA, 2007; pp 43-75.

(15) Heppner, D. E.; Kjaergaard, C. H.; Solomon, E. I. J. Am. Chem. Soc. 2013, 135, 12212. doi: 10.1021/ja4064525

(16) Heppner, D. E.; Kjaergaard, C. H.; Solomon, E. I. J. Am. Chem. Soc. 2014, 136, 17788. doi: 10.1021/ja509150j.

(17) Wan, Y. Y.; Du, Y. M.; Miyakoshi, T. S. Sci. China Ser. B 2008, 51, 669. doi: 10.1007/s11426-008-0071-y

(18) Rappoport, Z. The Chemistry of Phenols; Wiley: Hoboken, NJ, 2003.

(19) Weinshilboum, R. M.; Otterness, D. M.; Szumlanski, C. L. Annu. Rev. Pharmacol. Toxicol 1999, 39, 19. doi: 10.1146/ annurev.pharmtox.39.1.19

(20) Brown, C. K.; Vetting, M. W.; Earhart, C. A.; Ohlendorf, D. H. Annu. Rev. Microbiol. 2004, 58, 555. doi: 10.1146/annurev. micro.57.030502.090927

(21) Kovaleva, E. G.; Lipscomb, J. D. Science 2007, 316, 453. doi: 10.1126/science.1134697

(22) Zard, S. Z. Advances in Free Radical Chemistry, Vol. 2; Jai Press: Stamford, Conn., 1999.

(23) Chatgilialoglu, C.; Studer, A. Encyclopedia of Radicals in Chemistry, Biology and Materials; Wiley-Blackwell: Oxford, 
2012.

(24) Gerson, F.; Huber, W. Electron Spin Resonance Spectroscopy of Organic Radicals; Wiley-VCH: Weinheim, Great Britain, 2003.

(25) Buettner, G. R. Free Radic Biol. Med. 1987, 3, 259. doi: 10.1016/S0891-5849(87)80033-3

(26) Alberti, A.; Macciantelli, D. Spin Trapping. In Electron Paramagnetic Resonance, John Wiley \& Sons, Inc.: Hoboken, New Jersey, 2008; pp 285-324.

(27) Sanvoisin, J.; Langley, G. J.; Bugg, T. D. H. J. Am. Chem. Soc. 1995, 117, 7836. doi: 10.1021/Ja00134a041

(28) Spence, E. L.; Langley, G. J.; Bugg, T. D. H. J. Am. Chem. Soc. 1996, 118, 8336. doi: 10.1021/ja9607704

(29) Lin, G.; Reid, G.; Bugg, T. D. H. J. Am. Chem. Soc. 2001, 123, 5030. doi: $10.1021 / \mathrm{ja} 004280 \mathrm{u}$

(30) Xin, M.; Bugg, T. D. H. J. Am. Chem. Soc. 2008, 130, 10422. doi: $10.1021 / \mathrm{ja} 8029569$

(31) Brivio, M.; Schlosrich, J.; Ahmad, M.; Tolond, C.; Bugg, T. D. H. Org. Biomol. Chem. 2009, 7, 1368. doi: 10.1039/b821559f

(32) Mander, L. N.; Williams, C. M. Tetrahedron 2003, 59, 1105. doi: 10.1016/S0040-4020(02)01492-8
(33) Spirkova, K.; Kada, R. Chem. Pap. 1987, 41, 787.

(34) Babij, N. R.; McCusker, E. O.; Whiteker, G. T.; Canturk, B.; Choy, N.; Creemer, L. C.; De Amicis, C. V.; Hewlett, N. M.; Johnson, P. L.; Knobelsdorf, J. A.; Li, F. Z.; Lorsbach, B. A.; Nugent, B. M.; Ryan, S. J.; Smith, M. R.; Yang, Q. Org. Process. Res. Dev. 2016, 20, 661. doi: 10.1021/acs. oprd.5b00417

(35) Fulmer, G. R.; Miller, A. J. M.; Sherden, N. H.; Gottlieb, H. E.; Nudelman, A.; Stoltz, B. M.; Bercaw, J. E.; Goldberg, K. I. Organometallics 2010, 29, 2176. doi: 10.1021/om100106e

(36) Gunther, H. A. Nmr Spectroscopy: Basic Principles, Concepts and Applications in Chemistry, 3rd ed.; completely revised and updated edition.

(37) Pietruszka, J.; Wang, C. Green Chemistry 2012, 14, 2402. doi: $10.1039 / \mathrm{C} 2 \mathrm{GC} 35662 \mathrm{G}$

(38) Abdel-Mohsen, H. T.; Conrad, J.; Beifuss, U. J. Org. Chem. 2013, 78, 7986. doi: 10.1021/jo401193e

(39) Su, Y. J.; Jia, W.; Jiao, N. Synthesis-Stuttgart 2011, 1678. doi: $10.1055 / \mathrm{s}-0030-1260028$ 